\title{
DAYA HAMBAT PERTUMBUHAN ESCHERICHIA COLI DAN UJI HEDONIK YOGHURT DENGAN SUBSTITUSI TEPUNG MOCAF
}

\author{
Hajar Surya Wardani, Ninik Rustanti ${ }^{*}$ \\ Program Studi Ilmu Gizi Fakultas Kedokteran Universitas Diponegoro \\ Jl.Dr.Sutomo No.14, Semarang, Telp (024) 8453708, Email : gizifk@undip.ac.id
}

\begin{abstract}
Background : E. coli as a normal intestinal flora can be pathogenic. However, there are many preventions to prevent the growth of E.coli. One of the prevention efforts is by consuming products containing lactic acid bacteria (BAL). One of the products which contain BAL is yoghurt. BAL functions more effectively if combined with prebiotic. Mocaf is selected as prebiotic because during production, cassava raw material goes through fermentation stage by lactic acid bacteria which produce organic acids which function as antibacterial. This study aimed to discover the effect of Mocaf substitution as a prebiotic in Escherichia coli growth inhibitory and hedonic test of yoghurt .

Method: This is an experimental research with single factor completely randomized design which is have 5 levels of treatment of yoghurt Mocaf substitution variations with yoghurt Mocaf substitution as a control and yoghurt with $10 \%, 20 \%, 30 \%$ and 40\% Mocaf substitution. Statistical analysis from E.coli growth inhibitory used Kruskal-wallis test while hedonic test used Friedman test continued by Wilcoxon test.

Result : The highest diameter of clear zone as a parameter E.coli growth inhibitory was reached by yoghurt with $40 \%$ Mocaf substitution, which was 2,85 mm. Mocaf substitution didn't have significantly effect in smell, texture, color and flavor of yoghurt.
\end{abstract}

Summary : Yoghurt with 40\% Mocaf substitution had highest E.coli growth inhibitory

Keywords : Mocaf; growth inhibitory; E.col i; hedonic test; yoghurt

\begin{abstract}
ABSTRAK
Latar Belakang : E. coli sebagai flora normal usus dapat bersifat patogen. Namun dapat dilakukan upaya pencegahan dengan cara menghambat pertumbuhan E.coli semakin beragam. Salah satu upaya pencegahan tersebut adalah dengan konsumsi produk yang mengandung bakteri asam laktat (BAL). Salah satu produk yang mengandung BAL adalah yoghurt. Fungsi BAL lebih efektif jika dikombinasikan dengan prebiotik. Pemilihan tepung Mocaf sebagai prebiotik karena pada saat diproduksi, bahan baku singkong melalui tahap fermentasi oleh bakteri asam laktat yang akan menghasilkan asam-asam organik yang berfungsi sebagai antibakteri. Penelitian ini bertujuan untuk mengetahui pengaruh substitusi tepung Mocaf sebagai prebiotik pada yoghurt terhadap uji hedonik dan daya hambat pertumbuhan Escherichia coli.

Metode : Merupakan penelitian eksperimental dengan rancangan acak lengkap satu faktor yaitu variasi substitusi tepung Mocaf pada yoghurt dengan 5 taraf perlakuan yaitu yoghurt tanpa substitusi tepung Mocaf sebagai kontrol dan yoghurt dengan substitusi tepung Mocaf 10\%, 20\%, 30\% dan 40\%. Analisis statistik dari daya hambat pertumbuhan bakteri E.coli menggunakan uji Kruskal-wallis sedangkan uji kesukaan menggunakan uji Friedman dengan dilanjutkan uji Wilcoxon.

Hasil : Diameter zona bening sebagai parameter daya hambat pertumbuhan bakteri paling tinggi pada yoghurt dengan substitusi tepung Mocaf 40\% yaitu 2,85 mm. Substitusi tepung Mocaf tidak berpengaruh secara signifikan terhadap aroma, tekstur, warna, dan rasa yoghurt.
\end{abstract}

Simpulan : Yoghurt dengan substitusi tepung Mocaf $40 \%$ memiliki daya hambat pertumbuhan bakteri E.coli paling tinggi.

Kata kunci : Mocaf; daya hambat pertumbuhan; E.coli; uji hedonik; yoghurt

\section{PENDAHULUAN}

Dalam usus besar terdapat sekitar 400 spesies bakteri yang disebut mikroflora. Salah satu jenis mikroflora usus adalah Escherichia coli. ${ }^{1}$ E. coli berperan penting dalam sintesis vitamin $\mathrm{K}$, konversi pigmen-pigmen empedu, asam-asam empedu dan penyerapan zat-zat makanan. ${ }^{2,3}$ E. coli termasuk ke dalam bakteri heterotrof yang memperoleh makanan berupa zat organik dari lingkungannya karena tidak dapat menyusun sendiri zat organik yang dibutuhkannya. Zat organik diperoleh dari sisa organisme lain. Bakteri ini menguraikan zat organik dalam makanan

${ }^{*}$ Penulis Penanggungjawab 
menjadi zat anorganik, yaitu $\mathrm{CO}_{2}, \mathrm{H}_{2} \mathrm{O}$, energi, dan mineral.

Selain memberikan manfaat untuk tubuh, E. coli juga mempunyai sifat yang merugikan. $E$. coli dapat bersifat patogen jika jumlah bakteri ini meningkat dalam saluran pencernaan. E. coli menghasilkan enterotoksin yang menyebabkan beberapa kasus diare. E. coli berasosiasi dengan enteropatogenik menghasilkan enterotoksin pada sel epitel. ${ }^{3}$ Salah satu contoh kasus penyakit yang terjadi akibat infeksi bakteri $E$. coli yaitu serangan wabah E. coli yang melanda Jerman pada pertengahan bulan Maret 2011. Menurut WHO, wabah E. Coli yang melanda Jerman adalah bakteri E. Coli dari jenis Enterohaemorrhagic Escherichia coli (EHEC). E. coli jenis EHEC ini adalah jenis bakteri E. coli yang memproduksi Shiga-toxin.

Jika E. coli jenis EHEC menginfeksi manusia maka akan menyebabkan kejadian diare berdarah. Diare berdarah ini biasanya akan berkembang menjadi Haemolytic Uraemic Syndrome (HUS). HUS dapat menyebabkan kegagalan fungsi ginjal dan berbagai komplikasi infeksi lain. ${ }^{4}$ Berdasarkan The New England Journal of Medicine, pada kurun waktu bulan Mei hingga Juni 2011 di Jerman dilaporkan telah terjadi 3222 kasus infeksi bakteri E. coli. Angka ini sudah termasuk 39 kasus kematian yang disebabkan oleh infeksi bakteri $E$. coli. ${ }^{5}$

Upaya pencegahan infeksi oleh E.coli yang bersifat patogen dapat dilakukan dengan cara menekan pertumbuhan E.coli. Pertumbuhan E.coli pada saluran pencernaan dapat ditekan jika kondisi di dalam saluran pencernaan bersifat asam. ${ }^{6}$ Kondisi asam ini dapat terbentuk karena peran bakteri asam laktat (BAL) yang secara alami terdapat di dalam saluran pencernaan. ${ }^{7}$ Bakteri asam laktat di dalam saluran pencernaan memproduksi asam organik, hidrogen peroksida dan bakteriosin. Komponen-komponen tersebut dapat berperan penting dalam menghambat pertumbuhan E.coli yang bersifat patogen. ${ }^{8}$

Jumlah bakteri asam laktat yang secara alami terdapat di dalam saluran pencernaan dipengaruhi oleh faktor umur dan kesehatan individu. ${ }^{7}$ Fungsi bakteri asam laktat (BAL) dapat ditingkatkan dengan cara mengkonsumsi produk yang mengandung bakteri probiotik salah satu contohnya adalah yoghurt.

Yoghurt terbuat dari susu sapi segar atau produk susu olahan, bakteri starter, pemberi cita rasa dan penambahan susu skim sebagai pengental. ${ }^{9}$ Bakteri asam laktat yang digunakan sebagai starter dalam pembuatan yoghurt adalah kelompok Bakteri Asam Laktat (BAL) yaitu Streptococcus thermophilus dan Lactobacillus bulgaricus. Bakteri probiotik yang biasa ditambahkan kedalam yoghurt adalah Lactobacillus acidophilus, Lactobacillus casei, dan Bifidobacterium. ${ }^{6}$

Konsumsi probiotik lebih baik jika dikombinasikan dengan prebiotik. Prebiotik merupakan substrat yang tidak dapat dicerna tubuh tetapi dapat menstimulir pertumbuhan kelompok bakteri probiotik sehingga dapat menekan pertumbuhan bakteri patogen. ${ }^{10}$ Prebiotik difermentasi oleh bakteri di usus menghasilkan asam lemak rantai pendek terutama asam asetat dan asam laktat. Selain asam, bakteri usus juga akan menghasilkan zat anti mikroba. ${ }^{11}$ Asam laktat akan membantu meningkatkan kadar keasaman $\mathrm{pH}$ 4-5 sehingga dapat menghambat pertumbuhan bakteri patogen seperti E.coli. ${ }^{12}$

Prebiotik seperti inulin, oligosakarida, laktosukrosa dan laktosa secara alami dapat ditemukan pada biji-bijian, sayuran, buah-buahan serta umbi-umbian. ${ }^{13}$ Selain terdapat pada sumber makanan yang alami, oligosakarida juga dapat diperoleh dengan cara hidrolisis dengan asam atau proses hidrolisis enzim sellulase polisakarida, seperti pati dan serat kasar. ${ }^{14}$

Pada penelitian ini prebiotik yang akan disubstitusi pada yoghurt adalah tepung Mocaf. Tepung Mocaf dibuat dengan cara memfermentasi singkong dengan menggunakan bakteri asam laktat. ${ }^{15}$ Bakteri asam laktat akan memecah polisakarida dalam singkong menjadi oligosakarida seperti rafinosa. ${ }^{16}$ Adanya kandungan rafinosa inilah yang diharapkan dapat meningkatkan produksi asam laktat pada yoghurt agar mampu menstimulir penurunan $\mathrm{pH}$ di dalam saluran pencernaan sehingga dapat menghambat pertumbuhan E.coli.

\section{METODA}

Penelitian yang dilakukan ditinjau dari segi keilmuan termasuk dalam bidang Food Production, yang dilaksanakan pada bulan AprilOktober 2012 di Laboratorium Fisiologi dan Biokimia Fakultas Peternakan Universitas Diponegoro Semarang dan Laboratorium Ilmu Teknologi Pangan Jurusan Gizi Fakultas Ilmu Kesehatan Universitas Muhammadiyah Semarang.

Penelitian ini merupakan penelitian eksperimental dengan rancangan acak lengkap satu faktor yaitu variasi substitusi tepung Mocaf pada yoghurt dengan 5 taraf perlakuan meliputi (1) Yoghurt tanpa substitusi tepung mocaf sebagai 
kontrol, (2) Yoghurt dengan variasi substitusi tepung Mocaf 10\%, (3) Yoghurt dengan variasi substitusi tepung Mocaf 20\%, (4) Yoghurt dengan variasi substitusi tepung Mocaf 30\%, dan (5) Yoghurt dengan variasi substitusi tepung Mocaf $40 \%$. Setiap perlakuan dilakukan 5 kali pengulangan dan setiap pengukuran dilakukan secara duplo.

Sebelum penelitian utama, dilakukan penelitian dengan mengukur $\mathrm{pH}$ yoghurt. Pengukuran $\mathrm{pH}$ yoghurt bertujuan untuk memastikan yoghurt yang disubstitusi tepung mocaf mempunyai kualitas yang baik yaitu memiliki $\mathrm{pH}$ berkisar $3,5-4,5 .{ }^{17}$ Pengukuran $\mathrm{pH}$ dilakukan dengan menggunakan $\mathrm{pH}$ meter

Proses produksi yoghurt dengan substitusi tepung Mocaf diawali dengan proses pasteurisasi susu sapi segar, gula pasir, susu skim bubuk dan tepung Mocaf. Campuran bahan tersebut dipasteurisasi. Starter yoghurt ditambahkan apabila campuran susu sapi segar, gula pasir, susu skim dan tepung Mocaf telah dingin. Proses fermentasi berlangsung selama 12-16 jam. Tepung Mocaf yang digunakan didapatkan dari Koperasi Serba Usaha Gemah Ripah Loh Jinawi Trenggalek, Jawa Timur.

Pada penelitian utama, data yang dikumpulkan adalah daya hambat pertumbuhan $E$. coli pada yoghurt dengan substitusi tepung Mocaf dan uji hedonik pada yoghurt dengan substitusi tepung Mocaf. Daya hambat pertumbuhan E.coli diuji dengan mengunakan metode difusi agar. ${ }^{18}$ Penilaian uji hedonik untuk mengetahui tingkat kesukaan panelis terhadap yoghurt dengan substitusi tepung Mocaf menggunakan uji hedonik dengan lima skala hedonik, yaitu $1=$ Sangat tidak suka, 2=Tidak suka, 3=Netral, 4=Suka, dan 5=Sangat suka. Penilaian mutu organoleptik yoghurt dilakukan dengan uji hedonik pada panelis agak terlatih sebanyak 20 orang dari mahasiswa semester VI Program Studi Ilmu Gizi Fakultas Kedokteran Universitas Diponegoro.

Pengaruh variasi substitusi tepung Mocaf terhadap daya hambat pertumbuhan bakteri E.coli pada yoghurt diuji dengan Kruskall Wallis dan dilanjutkan dengan uji Mann-Whitney. Analisis pada uji hedonik digunakan uji Friedman yang dilanjutkan dengan uji Wilcoxon Signed Ranks.

\section{HASIL}

\section{A. Penelitian Utama}

\section{Pengukuran pH}

Hasil pengukuran $\mathrm{pH}$ yoghurt dengan variasi substitusi tepung Mocaf dapat dilihat pada Tabel 1

Tabel 1. Hasil pengukuran $\mathrm{pH}$ yoghurt dengan variasi substitusi tepung Mocaf.

\begin{tabular}{ll}
\hline Jenis Yoghurt & $\mathrm{pH}$ \\
\hline Tanpa substitusi (0\%) & 4,45 \\
Substitusi 10\% & 3,47 \\
Substitusi 20\% & 3,51 \\
Substitusi 30\% & 3,49 \\
Substitusi 40\% & 3,37 \\
\hline
\end{tabular}

Berdasarkan pengukuran $\mathrm{pH}$ didapatkan $\mathrm{pH}$ yoghurt bervariasi antara 3.37- 4.45. $\mathrm{pH}$ terendah terdapat pada yoghurt dengan substitusi tepung Mocaf sebanyak $40 \%$ $(\mathrm{pH}=3,37)$.Walaupun demikian hasil tersebut sudah memenuhi syarat standar $\mathrm{pH}$ yogurt yang berkualitas baik yaitu berkisar antara 3.5 $-4.5 .^{17}$

\section{Daya Hambat Pertumbuhan Bakteri E.coli}

Hasil uji daya hambat pertumbuhan E. coli pada yoghurt, menunjukkan substitusi tepung Mocaf sebagai prebiotik dapat meningkatkan daya hambat bakteri pada yoghurt. Daya hambat pertumbuhan bakteri ditunjukkan dengan diameter zona bening. ${ }^{18}$ 
Tabel 2. Hasil uji daya hambat pertumbuhan bakteri E. coli pada yogurt

\begin{tabular}{cc}
\hline Jenis Yoghurt & Diameter zona bening $(\mathrm{mm})$ \\
\hline Tanpa substitusi tepung Mocaf & $1,56 \pm 0,98$ \\
Substitusi tepung Mocaf $10 \%$ & $1,74 \pm 0,94$ \\
Substitusi tepung Mocaf $20 \%$ & $1,20 \pm 0,77$ \\
Substitusi tepung Mocaf $30 \%$ & $1,38 \pm 0,88$ \\
Substitusi tepung Mocaf 40\% & $2,85 \pm 0,39$ \\
\hline
\end{tabular}

Berdasarkan Tabel 2 di atas, dapat dilihat bahwa daya hambat partumbuhan E.coli tertinggi terdapat pada yoghurt dengan substitusi tepung Mocaf $40 \%$ yaitu $2,85 \mathrm{~mm}$. Daya hambat pertumbuhan E.coli pada yoghurt tanpa substitusi tepung Mocaf adalah 1,56 mm.

Hasil analisis data menggunakan uji Kruskall wallis menunjukkan tidak ada pengaruh substitusi tepung Mocaf terhadap daya hambat Escherichia coli pada yoghurt $(\mathrm{p}=0.07)$. (Lampiran 1$)$

\section{Uji Hedonik}

\section{a. Warna}

Hasil analisis uji hedonik warna yoghurt dengan substitusi tepung Mocaf dapat dilihat pada Tabel 3.

Tabel 3. Hasil Analisis Uji Hedonik pada Warna Yoghurt dengan Substitusi Mocaf

\begin{tabular}{cc}
\hline Jenis Yoghurt & Uji Hedonik (Warna) \\
\hline Tanpa substitusi tepung Mocaf & $3.45 \pm 0,86^{\mathrm{ab}}$ (netral) \\
Substitusi tepung Mocaf 10\% & $3.65 \pm 0.58^{\mathrm{a}}$ (suka) \\
Substitusi tepung Mocaf $20 \%$ & $3.30 \pm 0.92^{\mathrm{ab}}$ (netral) \\
Substitusi tepung Mocaf $30 \%$ & $3.25 \pm 0.85^{\mathrm{b}}$ (netral) \\
Substitusi tepung Mocaf 40\% & $3.05 \pm 0.99^{\mathrm{b}}$ (netral) \\
\hline
\end{tabular}

Keterangan : huruf superscript yang berbeda pada parameter menunjukkan beda nyata dari analisis Friedman

Yoghurt dengan substitusi tepung Mocaf $10 \%$ memiliki nilai kesukaan tertinggi yaitu 3.65 (suka), sedangkan yoghurt dengan substitusi $40 \%$ mempunyai nilai terendah yaitu 3,05 (netral).

Uji statistik dengan nilai $\mathrm{p}=0,020$ menunjukkan substitusi tepung Mocaf berpengaruh terhadap nilai kesukaan warna yoghurt. Jika dibandingkan dengan yogurt tanpa substitusi sebagai kontrol maka yogurt dengan substitusi Mocaf mempunyai nilai kesukaan terhadap warna tidak berbeda nyata secara statistik.

\section{b. Tekstur}

Hasil analisis uji hedonik tekstur yoghurt dengan substitusi tepung Mocaf dapat dilihat pada Tabel 4.

Tabel 4. Hasil Analisis Uji Hedonik pada Tekstur Yoghurt dengan Substitusi Mocaf

\begin{tabular}{cc}
\hline Jenis Yoghurt & Uji Hedonik (Tekstur) \\
\hline Tanpa substitusi tepung Mocaf & $3.45 \pm 1,05^{\text {ab }}$ (netral) \\
Substitusi tepung Mocaf $10 \%$ & $3.45 \pm 0.75^{\text {ab }}$ (netral) \\
Substitusi tepung Mocaf 20\% & $3.70 \pm 0.80^{\mathrm{a}}$ (suka) \\
Substitusi tepung Mocaf 30\% & $3.10 \pm 0.91^{\mathrm{b}}$ (netral) \\
Substitusi tepung Mocaf $40 \%$ & $2.45 \pm 0.99^{\mathrm{c}}$ (tidak suka) \\
\hline
\end{tabular}

Keterangan : huruf superscript yang berbeda pada parameter menunjukkan beda nyata dari analisis Friedman

Hasil uji hedonik terhadap tekstur menunjukkan yoghurt dengan substitusi tepung Mocaf 20\% memiliki nilai kesukaan tertinggi yaitu 3.70 (suka), sedangkan yoghurt dengan substitusi tepung Mocaf 40\% 
memiliki nilai kesukaan terendah yaitu 2.45 (tidak suka). Substitusi tepung Mocaf berpengaruh terhadap nilai kesukaan tekstur yoghurt $(\mathrm{p}=0,000)$

Dari sisi tekstur, secara statistik hanya yoghurt dengan substitusi tepung Mocaf $40 \%$ yang berbeda dengan yoghurt tanpa substitusi.
Yoghurt dengan variasi substitusi tepung Mocaf 10\%, 20\%, 30\% tidak berbeda nyata apabila dibandingkan dengan yoghurt tanpa substitusi.

\section{c. Aroma}

Hasil analisis uji hedonik aroma yoghurt dengan substitusi tepung Mocaf dapat dilihat pada Tabel 5.

Tabel 5. Hasil Analisis Uji Hedonik pada Aroma Yoghurt dengan Substitusi Mocaf

\begin{tabular}{cc}
\hline Jenis Yoghurt & Uji Hedonik (Aroma) \\
\hline Tanpa substitusi tepung Mocaf & $3.65 \pm 1,04^{\mathrm{a}}$ (suka) \\
Substitusi tepung Mocaf 10\% & $3.30 \pm 0.92^{\mathrm{a}}$ (netral) \\
Substitusi tepung Mocaf 20\% & $3.50 \pm 0.88^{\mathrm{a}}$ (netral) \\
Substitusi tepung Mocaf $30 \%$ & $3.25 \pm 0.85^{\mathrm{a}}$ (netral) \\
Substitusi tepung Mocaf 40\% & $2.20 \pm 1.00^{\mathrm{b}}$ (tidak suka) \\
\hline
\end{tabular}

Keterangan : huruf superscript yang berbeda pada parameter menunjukkan beda nyata dari analisis Friedman

Hasil uji hedonik terhadap aroma menunjukkan yoghurt tanpa substitusi tepung Mocaf memiliki nilai kesukaan tertinggi yaitu 3.65 (suka), sedangkan yoghurt dengan substitusi tepung Mocaf 40\% memiliki nilai kesukaan terendah yaitu 2.20 (tidak suka). Uji statistik menunjukkan bahwa substitusi tepung Mocaf berpengaruh terhadap nilai kesukaan aroma yang ditunjukkan dengan nilai $\mathrm{p}=0,000$.

Berdasarkan uji statistik diketahui hanya yoghurt dengan substitusi tepung Mocaf $40 \%$ yang mempunyai aroma yang berbeda dengan yoghurt tanpa substitusi. Akan tetapi yoghurt dengan variasi substitusi tepung Mocaf 10\%, 20\% serta $30 \%$ tidak mempunyai aroma yang berbeda apabila dibandingkan dengan yoghurt tanpa substitusi.

\section{d. Rasa}

Hasil analisis uji hedonik rasa yoghurt dengan substitusi tepung Mocaf dapat dilihat pada Tabel 6.

Tabel 6. Hasil Analisis Uji Hedonik pada Rasa Yoghurt dengan Substitusi Mocaf

\begin{tabular}{cc}
\hline Jenis Yoghurt & Uji Hedonik (Rasa) \\
\hline Tanpa substitusi tepung Mocaf & $2.90 \pm 0.96^{\mathrm{ab}}$ (netral) \\
Substitusi tepung Mocaf $10 \%$ & $2.90 \pm 1.02^{\mathrm{ab}}$ (netral) \\
Substitusi tepung Mocaf $20 \%$ & $2.60 \pm 0.94^{\mathrm{ab}}$ (netral) \\
Substitusi tepung Mocaf $30 \%$ & $2.85 \pm 1.04^{\mathrm{b}}$ (netral) \\
Substitusi tepung Mocaf 40\% & $2.10 \pm 0.78^{\mathrm{c}}$ (tidak suka) \\
\hline
\end{tabular}

Keterangan : huruf superscript yang berbeda pada parameter menunjukkan beda nyata dari analisis Friedman

Yoghurt tanpa substitusi tepung Mocaf dan yoghurt dengan substitusi tepung Mocaf sebesar 10\%, 20\%, dan $30 \%$ memiliki nilai kesukaan yang sama yaitu netral, sedangkan yoghurt dengan substitusi tepung Mocaf $40 \%$ memiliki tingkat kesukaan terhadap rasa terendah yaitu 2.10 (tidak suka).
Uji statistik menunjukkan bahwa substitusi tepung Mocaf berpengaruh terhadap nilai kesukaan aroma yang ditunjukkan dengan nilai $\mathrm{p}=0,004$.

Dari segi rasa, secara statistik yoghurt dengan substitusi tepung Mocaf $40 \%$ berbeda dengan yoghurt tanpa substitusi tepung Mocaf, 
sedangkan yoghurt dengan variasi substitusi tepung Mocaf yang lain tidak berbeda.

\section{PEMBAHASAN}

\section{1. pH yoghurt}

Berdasarkan hasil pengukuran $\mathrm{pH}$ menggunakan $\mathrm{pH}$ meter, dapat dilihat bahwa variasi substitusi tepung Mocaf sebagai prebiotik berpengaruh terhadap penurunan $\mathrm{pH}$ yoghurt. Apabila dibandingkan dengan $\mathrm{pH}$ yoghurt tanpa substitusi, yoghurt dengan substitusi tepung Mocaf mempunyai nilai $\mathrm{pH}$ lebih rendah. Jumlah prebiotik sebagai bahan yang digunakan untuk fermentasi bakteri asam laktat mempengaruhi $\mathrm{pH}$ yoghurt. Selain itu nilai $\mathrm{pH}$ yoghurt dipengaruhi oleh suhu, waktu inkubasi, dan jumlah starter. ${ }^{17}$ Namun nilai $\mathrm{pH}$ mengalami penurunan yang tidak linier, hal ini dapat disebabkan karena suhu media tidak terukur sama saat penambahan bakteri starter yoghurt.

\section{Daya hambat pertumbuhan E.coli}

Hasil uji daya hambat pertumbuhan bakteri menunjukkan bahwa substitusi tepung Mocaf 40\% mempunyai daya hambat pertumbuhan bakteri yang paling tinggi. Hal ini dapat dilihat dari hasil pengukuran diameter zona bening sebagai parameter daya hambat pertumbuhan bakteri. Akan tetapi apabila dianalisis secara statistik tidak bermakna disebabkan karena rentang variasi substitusi tepung Mocaf yang tidak besar.

Daya hambat pertumbuhan bakteri dipengaruhi oleh beberapa faktor seperti suhu, penurunan $\mathrm{pH}$, ketersediaan oksigen, adanya bakteriosin dan jumlah serta jenis prebiotik. ${ }^{19} \mathrm{pH}$ merupakan salah satu faktor yang dominan. Hal ini terlihat pada besarnya diameter zona bening sebagai parameter daya hambat pertumbuhan E.coli yang berbanding terbalik dengan nilai $\mathrm{pH}$ yoghurt. Semakin rendah nilai $\mathrm{pH}$ yoghurt maka semakin besar daya hambat pertumbuhan E.coli. Bakteri patogen biasanya tidak tahan terhadap kondisi asam, bakteri E. coli tidak dapat bertahan hidup pada dibawah $\mathrm{pH} 4{ }^{20}$

Daya hambat pertumbuhan bakteri yoghurt dengan substitusi tepung Mocaf lebih tinggi dibandingkan dengan yoghurt tanpa substitusi tepung Mocaf. Hal ini disebabkan adanya kandungan rafinosa yang berfungsi sebagai prebiotik pada tepung Mocaf yaitu sebesar 4,21 ppm. Beberapa jenis Oligosakarida yang tidak dicerna di dalam saluran pencernaan seperti rafinosa telah diketahui dapat meningkatkan jumlah Bifidobakterium dan BAL lainnya. ${ }^{21}$

Rafinosa akan difermentasi oleh bakteri asam laktat melalui proses glikolisis yang akan memecah glukosa menjadi piruvat atau asam laktat. Asam laktat yang dihasilkan akan menurunkan $\mathrm{pH}$ sehingga menjadi asam, pada kondisi ini pertumbuhan bakteri patogen menjadi terhambat. $^{22}$

\section{Uji Kesukaan}

\section{a. Warna}

Berdasarkan pengamatan secara subyektif oleh panelis, didapatkan warna yoghurt yang hampir sama yaitu putih kekuningan. Panelis memberikan penilaian kesukaan terhadap warna yoghurt tidak berbeda antara yoghurt yang tidak disubstitusi maupun yang disubstitusi dengan tepung Mocaf.

Warna yoghurt yang putih kekuningan terbentuk dari bahan-bahan dasar yang digunakan dan proses fermentasi pada pengolahan yoghurt. Yoghurt dengan substitusi tepung Mocaf diolah dari susu sapi segar serta tepung Mocaf yang berwarna putih. Singkong sebagai bahan dasar awalnya berwarna kekuningan. Dengan adanya perlakuan fermentasi pada proses pembuatan tepung Mocaf akan terjadi penghilangan komponen yang menyebabkan warna coklat pada saat protein dipanaskan. Hal ini menyebabkan tepung Mocaf yang berwarna putih setelah difermentasi. ${ }^{16}$ Warna kekuningan pada yoghurt terbentuk karena adanya penambahan susu skim bubuk yang berwarna kekuningan.

Selain itu, selama proses fermentasi susu menjadi yoghurt terjadi sintesis vitamin B kompleks khususnya thiamin (vitamin $\mathrm{B}_{1}$ ) dan riboflavin (vitamin $B_{2}$ ), serta beberapa asam amino penyusun protein. ${ }^{23}$ Kandungan riboflavin juga dapat menyebabkan warna yoghurt menjadi kekuningan, hal ini disebabkan karena riboflavin dapat memberikan warna lemak pada susu menjadi kekuningan. ${ }^{24}$ 


\section{b. Tekstur}

Hasil uji kesukaan terhadap tekstur menunjukkan yoghurt dengan substitusi tepung Mocaf 20\% memiliki nilai kesukaan tertinggi yaitu 3,70 (suka), sedangkan yoghurt dengan substitusi tepung Mocaf 40\% memiliki nilai kesukaan terendah yaitu 2,45 (tidak suka). Hasil uji statistik menunjukkan hanya yoghurt yang disubstitusi tepung Mocaf $40 \%$ yang berbeda dengan kontrol.

Yoghurt dengan substitusi tepung Mocaf $20 \%$ memiliki tekstur yang paling disukai oleh panelis karena tekstur yoghurt memiliki tekstur kental khas yoghurt. Tekstur yoghurt dengan substitusi tepung Mocaf $40 \%$ tidak disukai oleh panelis, karena tekstur yoghurt menggumpal. Tekstur yoghurt ini dipengaruhi oleh rendahnya nilai $\mathrm{pH}$. Tekstur yoghurt yang menggumpal ini terbentuk dari agregasi asam pada misel kasein dan produksi eksopolisakarida (polimer glukosa yang dihasilkan dari bagian struktural dinding sel) oleh bakteri asam laktat. ${ }^{25}$ Asam yang diproduksi selama proses fermentasi menyebabkan kasein mengalami penggumpalan dan tekstur akan menjadi padat. ${ }^{26}$ Karakteristik tersebut mempengaruhi tekstur yoghurt. Dengan demikian semakin besar substitusi tepung Mocaf maka tekstur yoghurt yang terbentuk akan semakin kental.

\section{c. Aroma}

Berdasarkan hasil uji hedonik aroma, nilai kesukaan tertinggi pada yoghurt tanpa substitusi tepung Mocaf, sedangkan yoghurt dengan substitusi tepung Mocaf 40\% memiliki nilai kesukaan terendah. Yoghurt tanpa substitusi tepung Mocaf memiliki aroma asam khas yoghurt. Aroma yoghurt ditentukan oleh terbenuknya asam laktat, asetaldehida, asam asetat dan asetil. Pada dasarnya aroma yoghurt disebabkan oleh terbentuknya asam laktat dan senyawa karbonil seperti asetaldehida. Asetaldehida dan beberapa komponen yang tidak teridentifikasi sebagai senyawa menyebabkan timbulnya aroma khas yoghurt. ${ }^{27}$ Pada yoghurt dengan substitusi tepung Mocaf 40\%, aromanya tidak disukai karena adanya aroma tepung pada yoghurt.

\section{d. Rasa}

Hasil uji hedonik panelis terhadap rasa menunjukkan yoghurt tanpa substitusi tepung Mocaf dan yoghurt dengan substitusi tepung Mocaf $10 \%$ mempunyai nilai kesukaan tertinggi dengan nilai rerata 2,90. Yoghurt dengan substitusi tepung Mocaf $40 \%$ memiliki tingkat kesukaan terendah dengan rerata 2,10. Berdasarkan uji statistik menunjukkan bahwa hanya yoghurt yang disubstitusi tepung Mocaf $40 \%$ yang berbeda dengan kontrol. Hal ini dikarenakan rasanya yang lebih asam dibandingkan yoghurt lainnya.

Cita rasa asam pada yoghurt timbul karena terbentuknya asam laktat dan asetaldehida. Selama fermentasi yoghurt, kultur starter mempunyai peranan penting, yaitu sebagai pembentuk asam sehingga menimbulkan rasa dan aroma yang khas serta pembentuk komponen cita rasa seperti karbonil, aldehid, aseton, asetoin, dan diasetil. Streptococcus thermophilus berperan dalam pembentukan asam dan menghasilkan rasa yang tidak tajam, sedangkan Lactobacillus bulgaricus lebih bersifat proteolitik dan menghasilkan rasa khas serta tajam jika diinokulasikan pada susu. ${ }^{28}$ Hasil metabolisme karbohidrat berupa asam-asam organik akan mempengaruhi cita rasa dan ikut menentukan kualitas yoghurt. ${ }^{29}$

\section{SIMPULAN}

1. Yoghurt dengan substitusi tepung Mocaf $40 \%$ memiliki daya hambat pertumbuhan bakteri E.coli lebih tinggi dibandingkan dengan yoghurt tanpa substitusi tepung Mocaf.

2. Uji kesukaan warna menunjukkan tidak ada perbedaan antara yoghurt yang disubstitusi tepung Mocaf dengan yoghurt tanpa substitusi. Uji kesukaan tekstur, aroma, rasa menunjukkan hanya yoghurt dengan substitusi tepung Mocaf $40 \%$ yang berbeda dengan yoghurt tanpa subsitusi.

\section{SARAN}

Sebaiknya substitusi tepung Mocaf sebagai prebiotik sebanyak $40 \%$ pada yoghurt karena akan menghasilkan daya hambat pertumbuhan E.coli yang paling tinggi sehingga mampu meningkatkan kualitas yoghurt sebagai minuman kesehatan. Untuk meningkatkan kesukaan terhadap aroma 
dan rasa yoghurt dengan substitusi tepung Mocaf $40 \%$ dapat ditambahkan flavor buah-buahan.

\section{DAFTAR PUSTAKA}

1. Silalahi, J. Makanan fungsional. Jakarta : Kanisius; 2006.

2. Tim Mikrobiologi Fakultas Kedokteran Universitas Brawijaya. Bakteriologi Medik. Malang : Bayumedia Publishing; 2003.

3. Jawetz et al. Mikrobioogi Kedokteran. Jakarta : Salemba Medika; 2001

4. World Health Organization. Public Health Review of The Enterohaemorrhagic Escherichia coli Outbreak in Germany. [online]. 2011. [dikutip pada 10 Oktober 2011]; Tersedia dari: URL: http://www.euro.who.int/en/what-we-do/healthtopics/disease-prevention/foodsafety/publications/2011/a-public-health-review-ofthe-enterohaemorrhagic-escherichia-coli-outbreakin-germany

5. Christina Frank et al. Epidemic Profile of ShigaToxin-Producing Escherichia coli O104 : H4 Outbreak in Germani-Preliminary Report. $N$ Engl $J$ Med 2011; 10.1056/nejmoa1106483.

6. Shah, N. P. Probiotic Bacteria : Selective Enumeration and Survival in

7. Dairy Foods. J. Dairy Sci 1999; 83 : 894-907.

8. Feri Kusnandar. Pemanfaatan talas, garut dan sukun sebagai prebiotik dan formulasi sinbiotik sebagai suplemen pangan [online]. 2007. [dikutip pada 17 Februari 2010]. Tersedia dari: URL: http://lppm.ipb.ac.id

9. Jacobsen, C. N. Screening of Probiotic Activities of Forty Seven Strain of Lactobacillus spp. by In Vitro Technique and Evaluation of The Colonization Ability of Five Selected Strain in Human. Applied and Enviromental Microbiology. 65.p.4949-4956. 1999.

10. De Vuyst L. IMDO : Industrial Microbiology, Fermentation Technology

11. and Downstream Processing. Departement of Industrial Microbiology; 2000. Page 55-56.

12. Collins, Gibson GR. Prebiotic, probiotic and synbiotic : approaches for modulating the microbial ecology of the gut. Am J Clin Nutr 1999; 69(5):1052S-1057S.

13. Tomomatsu, H. Health Effects of Oligosaccharides. Food Technology,. 1994. Oct: 61-64.

14. Usmiati. S, T. Utami. Pengaruh Bakteri Probiotik terhadap Mutu Sari Kacang Tanah Fermentasi. J.Pascapanen 2008; 5(2) : 27-36.

15. Wang, Yanbo. Prebiotics : Present and Future Science and Technology (Review), Food Research International 42, p8-12. 2008.
16. Roberfroid M, Slayin J. Nondigestable oligosaccharides. Crit Rev Food Sci Nutr 40:461480, 2000.

17. Subagio A, Siti W, Witono Y, Fahmi F. Prosedur Operasi Standar Produksi Mocaf Berbasis Klaster. Seafest Center IPB. Bogor. 2008.

18. Emil Salim. Mengolah Singkong Menjadi Tepung Mocaf Bisnis Produk Alternatif Pengganti Terigu. Lily Publisher. Yogyakarta. 2011.

19. James M. Jay, Martin J. Loser, David A. Golden. Modern food microbiology. New York: Springer; 2005. Page 165-169.

20. Srikandi Fardiaz. Penuntun praktek mikrobiologi pangan. Lembaga Sumberdaya Informasi IPB. Bogor. 1987.

21. Haynes, I.N. and M. J. Playne. Survival of Probiotic Culture in Low-Fat Ice Cream. Aust. J. Diary Tech. 57:3-7. 2002

22. Guraya R., J.F. Frank, and A.N. Hassan. Effectiveness of salt, $\mathrm{pH}$ and diacetyl as inhibitors of Escherichia coli 0157:H7 in dairy foods stored at refrigeration temperatures. J. Food Protect 1998; 61:1098-1102

23. Saufani, I. A. Korelasi Berbagai Level Prebiotik Ubi Jalar Kuning (Ipomea batatas L.) dan Probiotik Lactobacillus casei pada Pembuatan Susu Fermentasi Sinbiotik. Seminar Nasional Teknologi Peternakan dan Veterniter. 2009.

24. James L. Groff \& Sareen S. Gropper. Advanced nutrition and human metabolism. Third Edition. USA: Wadsworth; 2000. Page 48

25. Surajudin. Fauzi R. Kusuma. Dwi Purnomo. Yoghurt: Susu Fermentasi yang Menyehatkan. AgroMedia Pustaka. Jakarta. 2005.

26. Winarno F. G. Kimia Pangan dan Gizi. PT.Gramedia Pustaka Utama. Jakarta. 2004.

27. Beal et al. Combined Effects of Culture Conditions and Storage Time on Acidification and Viscocity of Stirred Yogurt. Journal Dairy Science 82:673-681. 1999.

28. Van der Berg, J. C. T. Dairy Technology in The Tropics and Sub Tropics. Netherland : Pudoc Wageningen. 1987.

29. Nizori et al. Soyghurt Synbiotic as a Functional Food Using Mixed Culture of Streptococus thermophillus, Lactobacillus bulgaricus and Lactobacillus acidophilus. Agroindustrial Technology Journal. ISSN : 0216 - 3160. Vol.18, no.1.p.28-33. 2008.

30. Jay, J.M. Modern Food Microbiology. 4th Ed. Van Nonstrand Reinhold. New York. 1992.

31. Yusmarini. Efendi, R. Evaluasi Mutu Soygurt yang Dibuat dengan Penambahan Beberapa Jenis Gula. Jurnal Natur Indonesia. 6(2):104-110. 2004. 